\title{
RESPON AGAMA TERHADAP PERSOALAN SOSIAL- EKONOMI: STUDI PEMIKIRAN TOKOH MUSLIM MUHAMMAD YUNUS DI BANGLADESH
}

\author{
Ibnu Farhan \\ IAI Bunga Bangsa Cirebon
}

\begin{abstract}
Abstrak: kemiskinan merupakan satu persoalan yang sampai hari dapat dengan mudah di temukan di beberapa belahan dunia, khususnya pada negara berkembang. Agama sebagai suatu yang diyakini manusia mampu menjadi solusi untuk mencapai kebahagiaan di dunia tentu saja mempunyai pandangan dan solusi akan hal ini. Tulisan ini akan mengkaji salah satu tokoh muslim, yaitu Muhammad Yunus yang telah berhasil mengembangkan satu sistem keuangan dalam bentuk Bank dengan nama Grameen Bank. Penelitian ini adalah studi pustaka dengan mengambil data dari karya-karya Muhammad Yunus. Kesimpulan dari penelitian ini menyatakan bahwa Grameen Bank yang didirikan Yunus telah mampu meningkatkan perekonomian masyarakat Bangladesh. Tidak seperti Bank pada umumnya bahwa Bank yang didirikan Muhammad Yunus adalah Bank yang mempunyai keberpihakan kepada masyarakat kecil yang lemah. Keberpihakan kepada yang lemah ini yang tentu saja merupakan salah satu nilai ajaran Islam yang diaplikasikan oleh Muhammad Yunus.
\end{abstract}

Kata Kunci: Kemiskinan, Sosial-Ekonomi, Grameen Bank

\section{A. Pendahuluan}

Salah satu persoalan yang ada di dalam kehidupan manusia sejak zaman dahulu adalah kemisikinan. Ia telah ada semenjak manusia hidup di dunia ini. Sejak itu pula para ahli di setiap zaman berusaha untuk menyelesaikan persoalan ini melalui beragam pendekatan seperti pendidikan, ekonomi, sosial, budaya dan sebagainya. Pentingnya penyelesaian terhadap masalah kemiskinan bukanlah tanpa alasan yang kuat. Beberapa penelitian telah 
menunjukan bahwa persoalan kemiskinan dapat menyebabkan timbulnya persoalan lain di masyarakat, meningkatnya angka kriminalitas, seperti pencurian dan perampokan (Prayetno, 2013: 30)

Kemiskinan mempunyai definisi yang begitu beragam, hal ini disebabkan keragaman indikator yang digunakan untuk mengukur itu. Secara sederhana kemiskinan dapat didefinisikan sebagai kondisi ketidakmampuan pendapatan dalam mencukupi kebutuhan pokok sehingga kurang mampu untuk menjamin kelangsungan hidup (Suryawati, 2004: 122). Dalam konteks Indonesia, sebagaimana tercantum dalam Undang-Undang No. 24 tahun 2004, bahwa kemiskinan adalah kondisi sosial ekonomi seseorang atau sekelompok orang yang tidak terpenuhinya hak-hak dasarnya untuk mempertahankan dan mengembangkan kehidupan yang bermartabat. Kebutuhan dasar yang menjadi hak tersebut meliputi kebutuhan pangan, kesehatan, pendidikan, pekerjaan, perumahan, air bersih, pertanahan, sumber daya alam, lingkungan hidup, rasa aman dari perlakuan atau ancaman tindak kekerasan dan hak untuk berpartisipasi dalam penyelenggaraan kehidupan sosial dan politik. Berkenaan dengan hal ini Chambers juga menambahkan bahwa di dalam kemiskinan biasanya terdapat lima dimensi yang dapat ditemukan yaitu, kemiskinan, ketidakberdayaan, kerentanan menghadapi situasi darurat, ketergantungan dan keterasingan.

Dalam membicarakan kemiskinan, setidaknya terdapat empat bentuk kemiskinan yang dikenal (Supardi, 2008: 3-4). Pertama, kemiskinan absolut yaitu kondisi di mana pendapatan seseorang atau kelompok orang tidak mencukupi untuk memenuhi kebutuhan standar kehidupan. Kedua, kemiskinan relatif yaitu kondisi kemiskinan yang disbabkan oleh pengaruh kebijakan pembangunan yang belum mampu menjangkau seluruh lapisan masyarakat sehingga menyebabkan ketimpangan distribusi pendapatan atau ketimpangan standar kesejahteraan. Daerah yang belum terjangkau ini disebut dengan daerah tertinggal. Ketiga, kemiskinan kultural di mana bentuk kemiskinan yang terjadi akibat adanya sikap dan kebiasaan seseorang atau masyarakat yang umumnya berasal dari satu budaya atau adat yang relatif menerima 
keadaan dan tidak mau memperbaiki taraf hidup dengan tata cara yang modern. Keempat, kemiskinan struktural yaitu bentuk kemisikinan yang disebabkan oleh rendahnya akses terhadap sumber daya yang terjadi pada satu tatanan sosial budaya dan politik yang kurang mendukung adanya pembebasan kemiskinan (BPS, 2008: 7-8).

Kemiskinan, sebagaimana disebutkan di atas, tentu juga menjadi perhatian di kalangan agamawan, agar dapat segera terselasaikan dengan baik. Dalam agama Islam misalnya, secara teologis, menyebut kemiskinan sebagai suatu yang harus segera diselesaikan dan menjadi tanggung jawab bagi semua muslim. Kemiskinan merupakan bahaya bagi seorang muslim karena dapat mengarahkan kepada kekufuran. Bahkan dalam al-Qur'an, Allah SWT mensifati mereka yang tidak mau terlibat dalam pengentasan kemiskinan sebagai orang yang mendustakan agama (QS. alMa'un: 3). Dalam ayat lain al-Qur'an juga mendorong kepada umat Islam untuk menolong orang miskin (QS. Al-Anfal: 60).

Islam sebagai satu sistem kepercayaan juga mengajarkan kepada umat Islam untuk berzakat, atau menyisihkan sebagaian kekayaannya untuk saudaranya yang membutuhkan. Zakat merupakan salah satu dari rukun Islam, dalam arti bahwa umat Islam yang tidak melakukannya, tidak bisa dikatakan sebagai seorang muslim yang sempurna. Zakat sendiri ada di berbagai kegiatan ekonomi umat Islam, seperti perniagaan, pertanian, peternakan bahkan yang terbaru adalah kewajiban zakat bagi seluruh profesi apapun yang dilakukan oleh umat Islam, seperti profesi dokter, guru, karyawan dan profesi lainnya selama itu memenuhi ketentuan dari nishab zakat. Zakat sendiri kemudian disalurkan kepada yang berhak dan yang berada pada urutan pertama dalam penerima zakat ini adalah mereka yang fakir dan miskin. Dengan demikian sudah jelas bahwa asas dari ajaran Islam adalah berusaha mengentaskan umatnya dari kemiskinan.

Meskipun Islam mendorong untuk mengentaskan kemiskinan, baik melalui al-Qur'an maupun Sunnah, namun dalam realitas dewasa ini sebagian penduduk muslim yang tinggal di beberapa negara yang juga mayoritas muslim masih mengalami persoalan kemiskinan. Meskipun tidak disangkal bahwa terdapat 
pula negara yang mayoritas muslim namun berkecukupan, namun hal itu lebih karena kekayaan dari sumber daya alamnya. Di antara negara yang berpenduduk muslim terbesar (150 juta jiwa) dan masih bergulat dengan persoalan ini adalah Bangladesh yang merupakan salah satu negara miskin yang ada di Asia. Beberapa hal yang menjadi penyebab dari kemiskinan di negara ini adalah jumlah populasi yang padat yang tidak sebanding dengan luas wilayahnya, rendahnya pendidikan, besarnya angka buta huruf, serta kebijakan pemerintahan yang tidak semuanya berpihak kepada rakyat dan juga bahwa Bangladesh adalah negara yang menjadi langganan bencana seperti banjir dan angin.

Di tengah kondisi seperti ini kemudian muncul satu tokoh penting dalam upaya mengentaskan kemiskinan di Bangladesh melalui pendekatan ekonomi, yaitu Muhammad Yunus. Ia tidak saja merupakan tokoh yang berpengaruh di Bangladesh, namun juga tokoh yang menginspirasi dunia berkat terobosan ekonominya. Hal ini setidaknya terbukti dengan dianugerakan kepadanya nobel perdamaian di tahun 2016, di mana pada tahun itu banyak pihak terkejut karena penghargaan itu jatuh kepadanya. Dalam satu kesempatan panitia menjelaskan atas dipilihnya Muhammad Yunus sebagai penerima nobel dengan menyatakan bahwa "tidak akan ada kedamaian selama masyarakat tidak bisa keluar dari kemiskinan". Sebuah kalimat yang menarik di mana agama Muhammad Yunus yaitu Islam yang juga berarti kedamaian.

Berdasarkan hal di atas, maka tulisan ini akan menjelaskan pemikiran dan gerakan ekonomi dalam rangka mengentaskan kemiskinan yang digagas oleh Muhammad Yunus melalui lembaga ekonominya yang diberi nama Grameen Bank di Bangladesh. Meskipun Grameen Bank tidak eksplisit disebut dengan sebuah Bank Islam, yang secara umum mengklaim menganut sistem ekonomi syariah sebagaimana dikenal di Indonesia, namun demikian penulis berasumsi bahwa setiap pemeluk agama tentu saja terpengaruh oleh agama yang dianutnya, dan itu tentu saja juga berlaku bagi Muhammad Yunus yang beragama Islam dan hidup di negara mayoritas muslim. 


\section{B. Pembahasan}

\section{Mengenal Sosok Muhammad Yunus}

Muhammad Yunus lahir pada 28 Juni 1940 di desa kecil Bathua dekat dengan Boxihrat Road di Hathazari Bangladesh. Ia merupakan anak ketiga dari 14 bersaudara. Ia lahir di kalangan keluarga muslim. Ayahnya bernama Hazi Dula Mia yang berprofesi sebagai tukang emas. Sedangkan ibunya bernama Sufia Khatun yang dermawan terhadap orang miskin yang pada gilirannya memberikan pengaruh yang kuat terhadap Muhammad Yunus sehingga ia memilih bidang studi Ilmu Ekonomi dan perubahan sosial. (Muhammad Yunus, 2008: 6-7)

Muhammad Yunus menghabiskan masa kecilnya di desa hingga tahun 1947. Ia beserta ayahnya kemudian pindah ke kota Chittagong, Bengali Timur di mana ayahnya memulai usaha emas permata. Di tempat ini Yunus mengenyam pendidikan dasar dan lanjutan sampai Ia menyelesaikan pedidikan sarjananya di jurusan ekonomi di Universitas Chittagong, sebuah perguruan tinggi yang didirikan oleh Inggris pada tahun 1836. Karena lulus dengan predikat yang sangat baik, Yunus kemudian mendapatkan beasiswa fullbright dan menerima gelar Ph. D di Amerika Serikat di Vanderblit University.

Yunus sempat bekerja di beberapa universitas di antaranya di Middle Tennessee State University Amerika Serikat. Di sini Yunus menikah dengan Vera Forostenko pada tahun 1970, namun pernikahannya tidak berlangsung lama karena Vera tidak mau menetap di Bangladesh. Pada tahun 1974 Yunus memutuskan pulang ke Bangladesh dan kemudian bekerja sebagai anggota komisi perencanaan pemerintah. Pada tahun 1980 Yunus kemudian menikah lagi dengan Afrozi Begum yang merupakan warga negara Bangladesh yang juga menjadi peneliti fisika terapan di University of Manchester.

Pekerjaan di pemerintahan rupanya membuat Yunus bosan, sehingga akhirnya Yunus memutuskan kembali ke dunia pendidikan dengan mengajar di Universitas Chittagong. Di tempat inilah kemudian ide tentang Grameen Bank muncul. Ide 
tentang Grameen Bank berawal dari pemandangan yang Yunus temukan setiap hari ketika melintasi sebuah desa bernama Jobra. Sebuah desa yang terletak antara tempat tinggal Yunus dan Kampus tempat ia mengajar. Yunus melihat bahwa desa Jobra ini memiliki tanah yang luas namun tandus. Ia betanya pada dirinya sendiri menggapa tanah ini tidak dimanfaatkan oleh pemilikinya? Jawaban itu kemudian Yunus temukan karena lahan pertanian di Jobra tidak memiliki cukup air.

Proyek pertama Yunus di Jobra adalah bekerjasama dengan masyarakat setempat untuk memperbaiki lahan tersebut agar bisa dipegunakan dengan membuat sitem irigasi. Ia membuat koperasi yang bertugas menjalankan sumur dan sistem distribusi air. Dan ternyata proyek ini berhasil dan mampu meningkatkan hasil panen di Jobra. Yunus tidak begitu saja puas dengan keberhasilan ini, karena terdapat fakta baru yang ia temukan di Jobra, bahwa masyarakat yang paling miskin tidak ikut merasakan keberhasilan pertanian di Jobra karena mereka tidak mempunyai lahan pertanian (Dimyati, 2014: 83).

Yunus dibantu dengan mahasiswanya kemudian melaksanakan riset yang lebih mendalam untuk mengetahui penyebab persoalan kemiskinan yang ada di Jobra. Melalui riset ini kemudian Yunus bertemu dengan seorang wanita bernama Sufiyah yang pekerjaanya adalah membuat bangku dari bambu. Untuk membeli bambu Sufiyah bergantung pada pinjaman rentenir, namun rentenir tersebut hanya mau meminjamkan jika Sufiyah mau menjual bangku buatannya tersebut kepada dirinya dengan harga yang teah ditentukan secara sepihak. Selain itu Sufiyah juga tetap dibebani bunga pinjaman yang tinggi, sehingga hal ini tidak memungkinkan baginya keluar dari kondisi kemiskinan. Mengetahui hal ini, Yunus kemudian meminjamkan uangnya yang berjumlah 27 dolar AS kepada Sufiyah agar terbebas dari rentenir. Sebuah langkah awal yang membuat Yunus terlibat lebih dalam dalam program kredit mikro dengan membentuk Grameen Bank.

Atas usahanya mengentaskan kemiskinan Yunus mendapatkan banyak penghargaan baik itu dalam skala 
nasional maupun internaisonal. Di antara penghargaan itu adalah:

1. Hadiah Budaya Asia Fukuoka XII tahun 2001

2. Nobel Peace Prize, Kategori Ekonomi tahun 2006

3. The Ecuadorian Peace Prize tahun 2007

4. Sebagai 25 orang paling berpengaruh di Bisnis selama 25 Tahun terakhir

5. The Raon Magsaysay Award

6. The Sidney Peace Prize

7. Dan banyak penghargaan lainnya.

Muhammad Yunus menulis beberapa karya di bidang ekonomi antara lain:

1. Banker to The Poor: The Autobiography of Muhammad Yunus of The Grameen Bank (1991)

2. Banker to The Poord: The Story of Grameen Bank (1991)

3. Banker to The Poor: Micro-Lending and The Battle Against World Poverty (2003)

4. Creating a World Without Poverty: Social Business and The Future of Capitalism: Building Social Business: The New Kind of Capitalism that Serves Humanity's Most Pressing Needs (2008) (Nurhayati, 2016: 47).

\section{Pemikiran Ekonomi Muhammad Yunus}

Pada paragraf di atas telah dijelaskan bahwa salah satu bentuk kemiskinan adalah kemiskinan struktural. Kemiskinan disebabkan oleh struktur yang ada baik itu struktur sosial, ekonomi maupun agama yang kemudian membiarkan realitas kemiskinan terus ada di masyarakat. Bentuk kemiskinan ini banyak mendapatkan perhatian dari para ahli, karena dinilai sebagai sesuatu yang kejam yang menindas masyarakat bawah. Beberapa solusi dikemukaan oleh para ahli, ada yang berhasil, namun beberapa solusi lain justru membuat kemiskinan semakin parah.

Secara konseptual Yunus menjelaskan beberapa hal yang terlebih dahulu harus dipahami oleh semua orang 
sehingga tergerak bersama-sama untuk menyelesaikan persoalan ini (Dimyati, 2014: 85). Pertama, bahwa kemiskininan adalah penyangkal seluruh hak asasi manusia. Bagi Yunus kemiskinan adalah absennya seluruh hak asasi manusia. Hal ini dapat menimbulkan rasa frustasi, permusuhan dan kemarahan yang pada akhirnya akan menghambat kedamaian di masyarakat. Karenanya untuk menuju kehidupan yang damai maka kemiskinan harus dicarikan solusinya (Muhammad Yunus, 2008: 263).

Kedua, untuk menyelesaikan persoalan itu maka langkah yang harus dilakukan adalah memperdayakan potensi ekonomi masyarakat miskin dengan cara melahirkan sebanyakbanyaknya wirausahawan baru (Nanih Machendrawati, 2001: 47). Kewirausahaan adalah keberanian seorang individu untuk melakukan usaha dalam rangka meningkatkan kesejahteraan hidupnya. Sedangkan kewirausahaan sosial merupakan keberanian melawan adat yang menjadi penghalang dan kemauan membangun solidaritas kelompok untuk melakukan usaha demi meningkatkan hidupnya. Konsep kewirausahaan sosial (social entrepreneurship) inilah yang digunakan oleh Yunus dalam mengentaskan kemiskinan dan mampu membuat perubahan multidimensiona pada masyarakat miskin khususnya perempuan di Bangladesh. Dengan cara kewirausahaan sosial ini maka akan muncul bisnis sosial di mana sekelompok masyarakat miskin dapat bersama-sama mengelola dan mendapat keuntungan dari usaha yang dijalankan.

Ketiga, bahwa dalam realitas kehidupan yang ada dewasa ini banyak kepalsuan-kepalsuan yang ada di dalam institusi-institusi yang secara kasat mata terlihat baik, namun justru sangat diskriminatif terhadap orang miskin sehingga bukan memberikan solusi justru melanggengkan kemiskinan. Yunus menyebutkan kepalsuan dari sistem perbankan dewasa ini. Bank sebagai lembaga ekonomi dibuat seharusnya dapat membantu kepada penguatan ekonomi masyarakat, namun ia sering kali tidak memperdulikan masyarakat miskin. Ia hanya berpihak kepada kepentingan pemodal dan orang kaya. Hal ini 
setidaknya dibuktikan bahwa bank hanya memberikan pinjaman kepada mereka yang mempunyai agunan sebagai jaminan hutangnya. Bank juga tidak membedakan antara pinjaman kepada mereka yang mampu dan mereka yang tidak mampu. Pada akhirnya bahwa fasilitas bank hanya dinikmati sebagian orang.

Kepalsuan lainnya ditemukan Yunus dalam institusi pendidikan. Menurutnya bahwa kurikulum yang ada di intitusi pendidikan tidak bersinggungan dengan realitas yang ada di masyarakat. Hal ini berdampak bahwa pendidikan hanya mempunyai manfaat secara teoritis saja tidak memberikan manfaat secara praktis. Perguruan tinggi hanya sebatas tempat diskusi, tapi tidak mempunyai dampak bagi masyarakat sekitarnya.

Kepalsuan juga ada di dalam agama atau lembaga agama yang Yunus anut yaitu Islam. Banyak kalangan agama mengutuk kemiskininan tapi mereka juga mengutuk solusinya dengan sistem perbankan yang dianggap sebagai suatu yang haram. Namun di sisi lain para pemuka agama hanya bisa berkhotbah saja, tidak melakukan tindakan nyata yang diperlukan masyarakat miskin.

Atas penjelasan di atas, Yunus kemudian bertekad mengentaskan kemiskinan dengan mendirikan salah satu lembaga keuangan yang tentu saja berbeda dengan lembaga keuangan yang ada di Bangladesh. Lembaga keuangan itu bernama Grameen Bank yang berpihak kepada masyarakat miskin. Menurut Yunus sebab kemiskinan itu bukan karena masyarakat malas atau tidak trampil, namun karena struktur yang tidak mendukung mereka untuk keluar dari kemiskinan tersebut.

\section{Grameen Bank Sebagai Usaha Mengentaskan Kemiskinan}

Grameen Bank bermakna The Village Bank atau bank desa resmi berdiri pada tanggal 1 oktober 1983. Grameen Bank didirikan sebagai solusi untuk mengentaskan kemiskinan di Bangladesh. Ia mempunyai satu tujuan yang hendak dicapai dengan sebuah falsafahnya "kredit kepada orang miskin adalah 
penting karena kredit dapat membantu meningkatkan pendapatan mereka dan memiliki kemampuan untuk mengembalkan kredit tersebut. Untuk membantu jutaan orang miskin keluar dari lembah kemiskinan, hendaknya dilakukan dengan menyediakan sumber permodalan yang dimanfaatkan oleh mereka dengan cara rasional dan komersial, tetapi dengan prosedur dan persyaratan yang sesuai dengan kondisi mereka (Mahmud Toha, 2000:16).

Tujuan dari Grameen Bank di antaranya sebagai berikut:

1. Memperluas fasilitas perbankan bagi orang-orang miskin

2. Menghapuskan eksploitasi oleh lintah darat

3. Menciptakan kesempatan untuk membuka lapangan kerja, dengan memanfaatkan sumber daya manusia yang kurang atau belum dimanfaatkan.

4. Menghimpun masyarakat yang kurang beruntung di dalam suatu bentuk organisasi yang dapat dimengerti dan dijalankan oleh mereka.

5. Memotong lingkaran setan yang sudah berlaku lama.

Untuk melaksanakan semua tujuan itu pada awalnya Yunus meminjam uang kepada Janata Bank sebanyak 10.000 Taka (\$300) ini sebagai modal awal untuk menyalurkan kredit kepada masyarakat miskin. Dana pinjaman dari lembaga lain semakin bertambah dari beberapa donatur lain, namun semuanya menjadi tanggung jawab Yunus, tentu saja karena Bank pemberi modal tidak mau berurusan dengan orang miskin di mana mereka diragukan mampu mengembalikan pinjamannya.

Setelah terkumpul modal yang cukup Yunus kemudian memulai usahanya untuk meminjamkan uang sebagai modal kepada orang miskin. Namun ada beberapa sistem yang berbeda yang diterapkan oleh Grameen Bank dibandingkan dengan Bank lainnya. Bank yang ada secara umum menurut Yunus tidak mampu dijangkau oleh masyarakat miskin karena mereka menerapkan beberapa hal, yaitu: 1) syarat agunan, yang 
tentu tidak bisa dipenuhi oleh orang miskin, 2) dokumen yang lengkap yang tentu juga sulit diakses oleh mereka yang buta huruf, 3) bagi bank kredit dengan nilai kecil itu akan merugikan dirinya, karena biaya operasionalnya sama. Sehingga tentu saja orang miskin tidak akan mengambil kredit yang besar.

Melihat kenyataan itu maka Yunus kemudian menyusun prinsip-prinsip penyaluran kredit, sehingga kredit tersebut dapat dinikmati oleh nasabah yaang miskin. Prinsipprinsip dari Grameen Bank adalah sebagai berikut: (1) kredit diberikan tanpa barang agunan, (2) tidak ada sanksi hukum jika ada penunggakan kredit, dan dibebaskan dari pinjaman jika anggota meninggal dunia, (3) anggota tidak perlu datang ke kantor, sebaliknya petugas bank yang datan menimui anggota, (4) prosedur perkreditan dibuat sesederhana mungkin dengan tidak menggunakan banyak formulir yang tidak dipahami anggota. (Pandu Suharto, 1989: 50).

Bagi anggota yang ingin menikmati fasilitas kredit di atas juga harus memenuhi beberapa persyaratan, yaitu:

1. Penerima fasilitas kredit adalah kelompok yang terdii dari 5 orang

2. Tinggal di dalam satu desa

3. Semua anggota wajib menghadiri pertemuan mingguan

4. Kelompok harus mengikuti latihan selama 1 minggu

Di samping hal di atas, perbedaan lain antara Grameen Bank dan Bank lainnya adalah bahwa Grameen Bank lebih menyalurkan kredit dalam nominal yang kecil daripada kredit nominal besar sebagaimana layaknya Bank secara umum. Selain itu bahwa mayoritas dari anggota yang meminjam dari Bank ini adalah perempuan. Bagi Yunus perempuan adalah yang paling memikirkan persoalan keperluan rumah tangga (Dimyati, 2014: 92).

Kredit mikro tentu saja melibatkan uang yang banyak. Dan dalam setiap program perkreditan tentu saja yang menjadi masalah adalah bagaimana membuat uang yang sudah disalurkan dapat kembali sehingga dapat digunakan untuk 
membantu anggota yang lain. Untuk mengurangi resiko kredit yang macet tesebut maka kemudian dibuat beberapa strategi yaitu dengan cara membentuk kelompok kecil solidaritas. Kelompok ini terdiri dari lima orang yang nanti di dalamnya diangkat ketua dan sekretaris. Anggotanya tidak diperkanankan terdiri satu keluarga tetapi jarak antar anggota juga diperkirakan dalam radius $300 \mathrm{~m}$. Kredit yang telah disalurkan kepada kelompok ini akan ditanggung bersama pembayarannya, yang dalam sistem masyarakat Indonesia disebut dengan tanggung renteng.

Di samping itu anggota dari kelompok ini juga diwajibkan untuk mengikuti pertemuan mingguan. Pertemuan ini diselenggarakan setiap minggunya dengan dihadiri 5-6 kelompok yang dilakukan secara disiplin. Selain diisi dengan acara pembekalan, dalam pertemuan ini juga diadakan latihan jasmani dan pembacaan 16 ikrar yang intinya adalah penanaman sikap disiplin, persatuan dan kerja keras untuk menciptakana kemakmuran bersama, dimulai dengan tempat tinggal yang layak, bersih, semangat bercocok tanam, hidup hemat dan mendidik anak-anak dalam keluarga (Nurhayati, 2016: 48).

Tidak seperti Bank pada umumnya di mana nasabah yang ingin meminjam uang harus ke kantor, Grameen Bank menerapkan pola yang terbalik, di mana petugas yang akan mendatangi nasabah yang akan meminjam. Petugas akan mensurvei terlebih dahulu kondisi nasabah dan kepentingan nasabah terhadap pinjaman tersebut. Hal ini agar kredit dapat diberikan secara benar dan bermanfaat.

Meskipun bertujuan untuk membantu orang miskin, Grameen Bank tetap menetapkan bunga atas dana yang dipinjam oleh anggotanya. Bunga tersebut tergantung pada tujuan dana itu digunakan. Apabila untuk usaha maka bunga yang diterapkan sekitar 20\%, Untuk keperluan perumahan sebesar $8 \%$ dan untuk biaya pendidikan sekitar 5\%. Adapun bagi pengemis Grameen Bank tidak membebankan bunga atas pinjamannya. 
Data yang terakhir penulis peroleh bahwa Grameen Bank telah memberikan kredit kepada 7 juta orang miskin di 73.000 desa di Bangladesh. Menarik bahwa lebih dari 90\% anggotanya adalah perempuan. Total dana yang telah digulirkan berjumlah $\$ 5.1 \mathrm{M}$ yang mungkin saja angka sekarang lebih besar lagi. Di samping itu angka pengembalian kredit dari anggotanya melebih $90 \%$, hal ini tentu saja sebuah prestasi yang sukses di dunia perbankan. Grameen Bank juga telah membentuk 25 bisnis sosial yang bergerak di berbagai bidang.

Berdasarkan deskripsi mengenai Grameen Bank di atas, dapat terlihat bahwa Yunus berusaha memadukan dua hal yang satu sama lain bertentangan. Satu sisi bahwa secara umum lembaga keuangan seperti Bank tentu saja berorientasi pada keuntungan sehingga dalam praktiknya sering kali mengabagaikan mereka yang dianggap tidak menguntungkan mereka, seperti orang miskin dan kelas ekonomi bawah. Tap di sisi lain, Yunus ingin menjadikan bahwa semua hal yang berkaitan dengan sistem ekonomi, termasuk bank di dalamnya harus juga memperhatikan aspek kemanusiaan, di mana adanya lembaga keuangan harus juga turut membantu mengentaskan kemiskinan. Hal ini yang kemudian Yunus lakukan dengan membuat Grameen Bank. Dan menarik bahwa meskipun suku bunga yang cukup tinggi dibandingkan bank konvensional yang ada, namun peminat dari Grameen Bank cukup tinggi. Setidaknya dalam kasus ini dapat terlihat bahwa memperoleh keuntungan tidak mesti harus mengabaikan nilai kemanusiaan.

\section{Kritik Terhadap Grameen Bank}

Meskipun berbagai penghargaan diterima oleh Muhammad Yunus atas usahanya mengentaskan kemiskinan dengan Grameen Bank, namun programnya tersebut tidak 
terlepas dari kritik. ${ }^{1}$ Beberapa kritik yang mengemuka antara lain adalaah:

Pertama, bagi kalangan pecinta Bank Syariah tentu saja Grameen Bank akan dijadikan sasaran kritik yang empuk, adanya bunga bagi penetapan kredit pinjaman. Yunus sendiri memang tidak menamakan Grameen Bank sebagai bank syariah. Grameen Bank memang menerapkan sistem perkreditan sebagaimana Bank secara umum, namun ia lebih difokuskan kepada masyarakat miskin.

Kedua, penerapan bunga yang berada di angka $20 \%$ dinilai cukup tinggi bagi sebagian pemerhati persoalan ini, sehingga timbul pertanyaan apakah benar bahwa tujuan dari Grameen Bank adalah membantu masyarakat miskin?

Ketiga, karena pengembalian kredit dibebankan kepada kelompok yang terdiri dari 5 orang tersebut, maka tunggakan pinjaman dari anggota kelompok itu ditanggung secara bersama-sama. Sampai di sini tidak ada persoalan, namun masalah muncul ketika anggota yang tidak mampu membayar kemudian mendapatkan tekanan dari anggota yang lain. Akibatnya ada semacam sanksi sosial bagi anggota yang belum mampu melunasi cicilanya sehingga tidak jarang akhirnya justru kembali lagi kepada sistem lama yaitu meminjam kepada lintah darat. Belum lagi bahwa mayoritas anggotanya adalah perempuan, di mana sering kali mendapatkan prilaku KDRT dari suaminya akibat rasa malu suami bila istrinya tidak mampu membayar cicilan pinjamannya.

\section{Kesimpulan}

Meskipun tidak terlepas dari kritik yang ditujukan atas program pengentasan kemiskinan melalui Grameen Bank, namun dunia mengakui bahwa program Yunus tersebut terbilang sukses dan menginspirasi. Setidaknya lebih dari 100 negara di dunia mengadopsi apa yang telah dilakukan oleh Yunus di Bangladesh. Mereka yang peduli terhadap persoalan sosial bahu membahu

\footnotetext{
${ }^{1}$ Kritik yang cukup dalam dilancarkan oleh Geger Riyanto dalam harian IndoProgress yang diterbitkan pada tanggal 14 November 2014 dengan judul "Kesadaran Sosial atau Kesadaran Asosial? Grameen Bank di antara Agensi Pelaksana dan Agensi Sosial.”.
} 
untuk mencontoh konsep Grameen Bank dengan tujuan membantu mereka yang tersisihkan.

Penting kiranya mengingat kembali apa yang disampaikan Yunus bahwa kerja keras dan ketrampilan yang dimiiki seseorang tidak begitu saja membawa orang tersebut keluar dari kemiskinan. Namun sistem yang berpihak adalah suatu hal yang jauh lebih penting. Dengan adanya sistem yang baik dan berpihak, mereka yang berada di bawah garis kemiskinan mempunyai kesempatan yang sama untuk membuktikan dirinya lebih baik lagi. Satu hal lagi yang bisa diambil dari Yunus adalah bahwa membantu masyarakat miskin dilakukan bukan dengan memberi ikan, namun memberikan kailnya.

Di sisi lain bahwa melalui Grameen Bank ini Yunus mengajarkan kepada para praktisi di lembaga keuangan, bahwa meskipun kegiatan ekonomi pada dasarnya bertujuan memperoleh keuntungan, namun hal tersebut tidak melulu harus mengabaikan mereka yang lemah. Kegiatan ekonomi dapat dilakukan untuk memperoleh keuntungan sekaligus juga membantu mereka yang lemah dan terbaikan. Dengan demikian, bahwa tujuan besar dari semua aktifitas ekonomi tidak melulu memperkaya satu golongan, namun juga harus mampu membawa kesejahteraan terhadap semua golongan yang ada di masyarakat.

Meskipun apa yang disampaikan Yunus di atas tidak menyinggung tentang Teologi Islam sebagai dasar gerakannya, namun penulis menilai bahwa Yunus yang merupakan seorang muslim tentu saja secara teologis terpengaruh dengan ajaran yang dianutnya yaitu Islam. Di dalam agama Islam terdapat satu ajaran tentang kewajiban untuk berpihak kepada mereka yang lemah, dan tentu saja dalam hal ini Yunus telah mengamalkan ajaran ini dengan sangat baik. [] 


\section{DAFTAR PUSTAKA}

Dimyati "Pengentasan Kemiskinan Model Muhammad Yunus" dalam Jurnal Irtifaq, Vol. 1, No. 2, UNHASY Jombang, 2014.

Mahmud Toga. 2000. Memberdayakan Usaha Kecil Melalui Grameen Bank. Jakarta: LIPI.

Muhammad Yunus dan Alan Jolis. 2007. Bank Kaum Miskin, Terj. Irfan Nasution. Depok: Marjin Kiri.

Muhammad Yunus. 2008. Menciptakan Dunia Tanpa Kemiskinan, Terj. Rani. Jakarta: Gramedia Pustaka Umum.

Nurhayati "Social Enterpreneurship Muhammad Yunus Grameen Bank" dalam Jurnal Bisnis, Manajemen dan Perbankan, Vol. 2, No. 1, Universitas Muhammadiyah Sidoarjo, 2016.

Pandu Suharto. 1999. Grameen Bank, Jakarta: LPPI.

Nanih Machendrawati \& Agus Ahmad. 2001. Pengembangan Masyarakat Islam, Bandung: Rosdakarya. 